\begin{tabular}{|c|c|c|c|}
\hline $\begin{array}{l}\text { RESEARCH } \\
\text { ARTICLE }\end{array}$ & $\begin{array}{r}\text { ADVANCE RESEARC } \\
\text { volume } 8 \mid \text { Issue } 2 \mid \text { D }\end{array}$ & $\begin{array}{l}\text { OCIAL SCIENCE } \\
-2231-6418\end{array}$ & \\
\hline $0=$ & DOI: 10.15740/HAS/ARJSS/8.2/270-272 & Visit us : www.researchjournal.co.in & \\
\hline
\end{tabular}

\title{
Exploring the link between violence against women and women involvement in illegal activities
}

Rashmee Yadav* and Mithlesh Verma

Department of Home Science (Extension Education and Communication Management), C.S. Azad University of Agriculture and Technology, KANPUR (U.P.) INDIA

(Email: rsm000786@gmail.com)

\section{ARTICLE INFO :}

$\begin{array}{lll}\text { Received } & : & 12.08 .2017 \\ \text { Revised } & : & 17.10 .2017 \\ \text { Accepted } & : & 01.11 .2017\end{array}$

\section{KEY WORDS :}

Criminal women, Crime (illegal activities), Violence

HOW TO CITE THIS ARTICLE :

Yadav, Rashmee and Verma, Mithlesh (2017). Exploring the link between violence against women and women involvement in illegal activities. Adv. Res. J. Soc. Sci., 8 (2) : 270-272, DOI: 10.15740/HAS/ARJSS/8.2/270-272.

*Author for correspondence

\begin{abstract}
The present study entitled, "Exploring the link between violence against women and women involvement in illegal activities" was carried in district Farrukhabad to assess the criminal women. Thus, one jail was selected with 100 respondents. After studying women involvement in different criminal activities (crime). Higher women involvement in domestic violence with 1.60 mean value and dowry death with 1.41 mean score value. Further, after studying their causes of dowry death crime, it was found that women respondents involved lack of education, 1.19 mean score, attempt to suicide, violence was increased 1.22 mean score and kidnapping, not good guidance with 1.22 mean score and domestic violence, social stress with 1.28 mean score, money is major causes of murder with 1.39 mean score and women respondents found the poverty causes of attempt murder with 1.40 mean score. Many women respondents have illtreatment by parent causes of prostitution with 1.19 mean score and women involved in drug trade, family occupation with 1.13 mean score, habited and not good guidance in robberies with 1.08 mean score, feeling neglect/ignored under appreciated causes of cheating with mean score. From the study, it was concluded that mostly women involved in crime domestic violence and dowry death etc. causes of family violence, money, lack of education, poverty, social stress etc.
\end{abstract}

